\title{
Effects of TGF- $\beta$ signaling blockade on human A549 lung adenocarcinoma cell lines
}

\author{
CHENG-CHENG XU, LEI-MING WU, WEI SUN，NI ZHANG，WEN-SHU CHEN and XIANG-NING FU \\ Department of General Thoracic Surgery, Tongji Hospital, Tongji Medical College, \\ Huazhong University of Science and Technology, Wuhan 430030, P.R. China
}

Received March 31, 2011; Accepted June 29, 2011

DOI: $10.3892 / \mathrm{mmr} .2011 .530$

\begin{abstract}
Transforming growth factor $\beta$ (TGF- $\beta$ ) is overexpressed in a wide variety of cancer types including lung adenocarcinoma (LAC), and the TGF- $\beta$ signaling pathway plays an important role in tumor development. To determine whether blockade of the TGF- $\beta$ signaling pathway can inhibit the malignant biological behavior of LAC, RNA interference (RNAi) technology was used to silence the expression of TGF- $\beta$ receptor, type II (TGF $\beta$ RII) in the LAC cell line, A549, and its effects on cell proliferation, invasion and metastasis were examined. Three specific small interfering RNAs (siRNAs) designed for targeting human TGF $\beta$ RII were transfected into A549 cells. The expression of TGF $\beta$ RII was detected by Western blot analysis. Cell proliferation was measured by MTT and clonogenic assays. Cell apoptosis was assessed by flow cytometry. The invasion and metastasis of A549 cells were investigated using the wound healing and Matrigel invasion assays. The expression of PI3K, phosphorylated Smad2, Smad4, Akt, Erk1/2, P38 and MMPs was detected by Western blot analysis. The TGF $\beta$ RII siRNA significantly reduced the expression of TGF $\beta$ RII in A549 cells. The knockdown of TGF $\beta$ RII in A549 cells resulted in the suppression of cell proliferation, invasion and metastasis and induced cell apoptosis. In addition to the Smad-dependent pathway, independent pathways including the Erk MAPK, PI3K/Akt and p38 MAPK pathways, as well as the expression of MMPs and VEGF, were inhibited. In conclusion, TGF- $\beta$ signaling is required for LAC progression. Therefore, the blockade of this signaling pathway by the down-regulation of TGF $\beta$ RII using SiRNA may provide a potential gene therapy for LAC.
\end{abstract}

Correspondence to: Dr Xiang-Ning Fu, Department of General Thoracic Surgery, Tongji Hospital, Tongji Medical College, Huazhong University of Science and Technology, 1095 Jiefang Avenue, Wuhan 430030, P.R. China

E-mail: fuxn2006@yahoo.com.cn

Key words: lung adenocarcinoma, A549 cells, transforming growth factor $\beta$, transforming growth factor $\beta$ receptor type II, RNA interference, gene therapy

\section{Introduction}

Lung cancer is the leading cause of cancer-related death worldwide (1-2). Lung adenocarcinoma (LAC), which accounts for approximately $40 \%$ of all lung cancers, is currently one of the most common histological types and its incidence has gradually increased in recent years in many countries (3). Although advances in combined treatment of non-small cell lung cancer (NSCLC) have improved survival and quality of life, the majority of patients succumb to the disease within 2 years and prognosis is relatively poor compared with other common cancers (15\% vs. 62-97\% 5-year overall survival rate) (1,3-5). Human LAC cells are characterized by marked growth, invasion and metastasis and contribute to the poor patient outcomes.

The transforming growth factor- $\beta$ (TGF- $\beta$ ) signaling pathway has been shown to play a key role in carcinogenesis and cancer progression (6-8). NSCLC specimens overexpress TGF- $\beta$, which has been detected by multivariate analysis to be an independent risk factor for pulmonary metastasis and correlates with decreased survival (9-10). TGF- $\beta$ binds to TGF- $\beta$ receptor, type II (TGF $\beta$ RII), which then phosphorylates and activates the type I receptor in the complex, and activates SMAD-dependent and -independent pathways. The non-SMAD signaling pathways are likely to mediate the positive effects on pro-carcinogenesis (6-8). Several investigators have reported that inactivation of the TGF- $\beta$ signaling pathway reduces the ability of human cancer cells to progress (11-14). Therefore, the TGF- $\beta$ signaling pathway, and in paticular the critical role played by TGF $\beta$ RII, may be a potential target for gene therapy in LAC.

RNA interference (RNAi) is a sequence-specific posttranscriptional gene-silencing process, which is initiated by double-stranded RNA (e.g., chemically synthetic small interfering RNAs). Consequently, the RNA-induced silencing complex (RISC) degrades targeted mRNA and inhibits protein expression (15). RNAi technologies are currently widely used as knockdown genes in functional genomics due to the effective, stable gene suppression provided by siRNAs (16).

In this study, we used the RNAi strategy to silence TGF $\beta$ RII expression and significantly inhibited the TGF- $\beta$ signaling pathway in the LAC cell line, A549. In the experiments described herein, we demonstrate that the capability for proliferation, invasion and metastasis is reduced and apoptosis 
is induced in TGFßRII-deficient A549 cells. In addition, the molecular mechanisms of the anti-tumor effects of the TGFßRII knockdown are initially revealed, which could lay the foundation for genetic therapy for LAC.

\section{Materials and methods}

Materials. The human LAC cell line, A549, was purchased from the Shanghai Institute of Biochemistry and Cell Biology, China Academy of Science. Cell culture medium, fetal bovine serum (FBS) and TRIzol reagent were from Life Technologies (Eggenstein, Germany). siRNAs (Genepharma, Shanghai, China) and Lipofectamine 2000 reagent (Invitrogen, Carlsbad, CA, USA) were prepared for transfection. 3-(4,5-Dimethylthiazol-2yl)-2,5-diphenyltetrazolium (MTT) and TGF 11 were purchased from Sigma Chemical Co. (St. Louis, MO, USA). RevertAid ${ }^{\text {Tw }}$ first strand cDNA synthesis kit was obtained from Fermentas Europe. Matrigel (BD Biosciences, Bedford, MA, USA) and Transwell plates (Costar Corning, Cambridge, MA, USA) were prepared for the Matrigel invasion assay. The Annexin V-FITC apoptosis dectection kit was purchased from KeyGen Biotech Co. (Nanjin, China). Antibodies against TGFßRII, PI3K, p-Akt, p-Erk1/2, p-P38, p-Smad2, Smad4, VEGF, MMP-2, MMP-9 and $\beta$-actin were purchased from Santa Cruz Biotechnology, Inc. (Santa Cruz, CA, USA). Antibodies against P38 and Akt were purchased from Cell Signaling Technology (Beverly, MA, USA). All other reagents were purchased from standard commercial suppliers unless otherwise specified.

Cell line and cell culture. The human LAC cell line, A549, was cultured in RPMI-1640 medium, supplemented with $10 \% \mathrm{FBS}, 100 \mathrm{U} / \mathrm{ml}$ penicillin, and $100 \mu \mathrm{g} / \mathrm{ml}$ streptomycin at $37^{\circ} \mathrm{C}$ in a humidified atmosphere containing $5 \% \mathrm{CO}_{2}$. Throughout the experiment, cells were used in the logarithmic phase of growth.

Design and transfection of synthetic siRNAs. Three specific siRNA oligonucleotides targeting TGF $\beta$ RII, which were based on the human TGFßRII gene (NM_003242.5), one scrambled non-targeting siRNA (mock) and one fluorescent siRNA were designed and synthesized. The target (5' to $3^{\prime}$ ) and the siRNA sequences, designated as TGFßRII-3866(SiT1), TGF $\beta$ RII-3047(SiT2) and TGFßRII-475(SiT3) are shown in Table I. Prior to transfection, A549 cells were cultured in the well plates for $24 \mathrm{~h}$. After they had reached an $80 \%$ density/ well, cells were transfected with $100 \mathrm{nM}$ siRNA using Lipofectamine 2000 reagent, following the manufacturer's protocol. The cells were harvested 24, 48, or $72 \mathrm{~h}$ after transfection for analyses. Additionally, A549 cells that had been either untreated or treated only with Lipofectamine 2000 reagent were used as controls.

Western blot analysis. Cells were washed in phosphate buffered saline (PBS), and lysed with RIPA buffer (50 mM Tris- $\mathrm{HCl}, 150 \mathrm{mM} \mathrm{NaCl}, 1 \%$ Triton X-100, 0.1\% SDS, $1 \%$ sodium deoxycholic acid, $1 \mathrm{mM}$ sodium orthovanadate, $1 \mathrm{mM}$ PMSF and protease inhibitor cocktail). Protein concentrations were measured by the Bradford method using BCA protein assay reagent (17). Protein samples $(20 \mu \mathrm{g} /$ well $)$ were separated by $10 \%$ SDS-PAGE, electrophoretically transferred to
PVDF membranes, and the membranes were blocked for $2 \mathrm{~h}$ at room temperature with 5\% non-fat dried milk in TBS-T (10 mM Tris- $\mathrm{HCl}, 100 \mathrm{mM} \mathrm{NaCl}$, and $0.1 \%$ Tween-20). The membranes were then incubated with primary antibodies (1:2000) overnight at $4^{\circ} \mathrm{C}$, followed by secondary antibodies against rabbit or mouse IgG conjugated to horseradish peroxidase (1:3000) for $2 \mathrm{~h}$ at room temperature. Finally, they were developed with ECL detection reagents. Protein expression was quantified by densitometry and normalized to $\beta$-actin expression.

Purification of total cellular $m R N A$ and reverse transcription$P C R$. Total RNA was extracted from cells using the TRIzol reagent according to the manufacturer's protocol, cDNA was generated by reverse transcription of total cellular RNA with the First Strand cDNA Synthesis Kit. PCR amplification was performed in a $25 \mu \mathrm{l}$ reaction mixture containing $12.5 \mu \mathrm{l}$ RT-PCR Master Mix, $10 \mu \mathrm{l}$ double distilled water, $1.5 \mu \mathrm{l}$ cDNA, $0.5 \mu \mathrm{l}$ forward primer and $0.5 \mu \mathrm{l}$ reverse primer for 30 cycles. Primers used for amplification of cDNA were as follows: TGFßRII, forward, 5'-GAGGAGCGGAAGACGG AGTT-3' and reverse, 5'-TGTCATTTCCCAGAGCACCAG-3'; GAPDH,forward,5'-CCACCCATGGCAAATTCCATGGCA-3' and reverse, 5'-TCTAGACGGCAGGTCAGGTCCACC-3. The following conditions were used for PCR: $94^{\circ} \mathrm{C}$ for $30 \mathrm{sec}$, $60^{\circ} \mathrm{C}$ for $30 \mathrm{sec}, 72^{\circ} \mathrm{C}$ for $40 \mathrm{sec}, 30$ cycles and $72^{\circ} \mathrm{C}$ for $5 \mathrm{~min}$ for final extension. The PCR products were separated on a $1.5 \%$ agarose gel, visualized under UV light and photographed.

Cell proliferation assay. Cell proliferation was detected by MTT assay. A549 cells were seeded in 96-well plates at a density of $1 \times 10^{4}$ cells/well. After $24 \mathrm{~h}$, the cells were transfected with siRNA and incubated with $2 \mathrm{ng} / \mathrm{ml}$ TGF- $\beta 1$ for 0-72 h. Cell proliferation was determined by adding MTT $(5 \mathrm{mg} / \mathrm{ml})$ and further incubating the cells for $4 \mathrm{~h}$, then the precipitate was solubilized by the addition of $150 \mu \mathrm{l} /$ well DMSO (Sigma) and shaken for $10 \mathrm{~min}$. Absorbance at a wavelength of $490 \mathrm{~nm}$ in each well was measured with a microplate reader (Bio-Tek ELX800, USA). All experiments were performed in triplicate and the experiment was repeated on at least three separate occasions.

Clonogenic assay. Cells transfected with siRNA after $48 \mathrm{~h}$ were seeded in 6-well plates at densities of 300 cells/well and incubated for 14 days at $37^{\circ} \mathrm{C}$ in a humidified atmosphere of $5 \% \mathrm{CO}_{2}$. The colonies were fixed in $4 \%$ paraformaldehyde at room temperature for $30 \mathrm{~min}$, stained with $0.1 \%$ crystal violet for $10 \mathrm{~min}$ and, finally, positive colony formation ( $>50$ cells/ colony) was counted and colony formation rate was calculated. These experiments were repeated three times.

Wound healing assay. A549 cells were transfected with siRNAs in 6-well plate. After $48 \mathrm{~h}$, the cells were at $90 \%$ confluency/well, and scratched with a $200 \mu 1$ pipette tip. Plates were washed twice with PBS to remove detached cells and incubated with the complete growth medium without FBS. Cells migrated into the wounded area, and photographs were taken immediately $(0 \mathrm{~h})$ and at $24 \mathrm{~h}$ (magnification, $\mathrm{x} 40$ ). Results were expressed as a migration index: the distance migrated by siRNA-treated cells (mock or targeted) relative 
Table I. Sequences of human TGF $\beta$ RII siRNA and negative control.

\begin{tabular}{|c|c|c|}
\hline siRNA & Target sequences ( $5^{\prime}$ to $\left.3^{\prime}\right)$ & siRNA duplex sequences (5' to $3^{\prime}$ ) \\
\hline \multirow[t]{2}{*}{ TGF $\beta$ RII-3866 (SiT1) } & (3866)GAAACTTGTTAATCAACAA & GAAACUUGUUAAUCAACAATT \\
\hline & - & UUGUUGAUUAACAAGUUUCTT \\
\hline \multirow[t]{2}{*}{ TGF $\beta$ RII-3047 (SiT2) } & (3047)GGAGCAAATTCTCACTCTA & GGAGCAAAUUCUCACUCUATT \\
\hline & - & UAGAGUGAGAAUUUGCUCCTT \\
\hline \multirow[t]{2}{*}{ TGFßRII-475 (SiT3) } & (475)GGTTAATAACGACATGATA & GGUUAAUAACGACAUGAUATT \\
\hline & - & UAUCAUGUCGUUAUUAACCTT \\
\hline \multirow[t]{2}{*}{ Negative control } & - & UUCUCCGAACGUGUCACGUTT \\
\hline & - & ACGUGACACGUUCGGAGAATT \\
\hline
\end{tabular}

to the distance migrated by untreated cells. Experiments were performed in triplicate and repeated at least three times.

Matrigel invasion assay. Matrigel invasion assay was performed using Transwell chambers. Briefly, the $8-\mu \mathrm{m}$ pore size filters were coated with $100 \mu \mathrm{l}$ of $1 \mathrm{mg} / \mathrm{ml}$ Matrigel $500 \mu \mathrm{l}$ RPMI1640 medium containing 10\% FBS was added to the lower chambers. After transfection with siRNA for $48 \mathrm{~h}$, cells were harvested and homogeneous single cell suspensions ( $2 \times 10^{5}$ cells/well) were added to the upper chambers. The invasion lasted for $24 \mathrm{~h}$ at $37^{\circ} \mathrm{C}$ in a $\mathrm{CO}_{2}$ incubator. Subsequently, noninvasive cells on the upper surface of the filters were carefully scraped off with a cotton swab, and cells migrated through the filters were fixed and stained with $0.1 \%$ crystal violet for $10 \mathrm{~min}$ at room temperature, examined and photographed by microscopy (magnification, x200). Quantification of migrated cells was performed.

Flow cytometric analysis of apoptosis. Following transfection for $48 \mathrm{~h}$, cells were exposed to TGF $\beta 1(2 \mathrm{ng} / \mathrm{ml})$ for $24 \mathrm{~h}$. Cells in 6-well plates were harvested in $500 \mu \mathrm{l}$ of binding buffer, stained with $5 \mu \mathrm{l}$ Annexin V-FITC and $5 \mu \mathrm{l}$ prodium iodide for $10 \mathrm{~min}$, and subjected to flow cytometric analysis by a CycleTEST ${ }^{\mathrm{TM}}$ PLUS (Becton-Dickinson, San Jose, CA, USA) within $1 \mathrm{~h}$. The results were quantified using CellQuest and ModFit analysis software.

Statistical analysis. All data were shown as the means \pm standard deviation. Statistical significance was determined by analysis of variance using the SPSS 12.0 software package. The level for statistical differences was set at a value of $\mathrm{P}<0.05$.

\section{Results}

Expression of TGFRRII protein and $m R N A$ in NSCLC cell line A549. To determine whether TGF $\beta$ RII was overexpressed in the NSCLC cell line, A549, its TGF 3 RII expression was examined using the Western blot, RT-PCR and immunochemical analyses, and HFL-1 (human fetal lung fibroblasts) and HepG2 (human hepatoma cells), which express TGF $\beta$ RII, were used as the positive controls. The results of the Western blot analysis revealed that TGF $\beta$ RII protein was significantly over-expressed in A549 cells in comparison with HFL-1 $(\mathrm{P}<0.01)$ and HepG2 cells $(\mathrm{P}<0.05)$ (Fig. 1A), results that were consistent with RT-PCR (Fig. 1B; P<0.05).
Transfection efficiency examination. To ensure the transfection efficiency of TGF $\beta$ RII siRNA, $100 \mathrm{nM}$ fluorescent siRNA mixed with Lipofectamine 2000 were transfected into A549 cells cultured in a 6-well plate. The transfection efficiency was examined by flow cytometry $6 \mathrm{~h}$ post-transfection and by fluorescence microscopy $6,12,24$, and $48 \mathrm{~h}$ post-transfection. Flow cytometry revealed that approximately $86 \%$ of the cells were transduced (Fig. 2A). Fluorescence could be observed by fluorescence microscopy $6,12,24$, and $48 \mathrm{~h}$ after transfection, and became gradually more intense (Fig. 2B). The results revealed that transfection was successful. Considering the toxicity of Lipofectamine 2000 and the transfection efficiency, $5 \mu \mathrm{l} /$ well in 6 -well plates was used in the following experiments.

Knockdown of TGF $\beta$ RII by siRNA. Three TGF $\beta$ RII -siRNA targeting different encoding regions of human TGF $\beta$ RII mRNA, named siT1, siT2 and siT3 and scrambled siRNA (mock) at 100 nM were transfected into A549 cells for 48 h to identify the siRNA sequence that most markedly suppressed TGF $\beta$ RII. The siRNA sequences for these siRNA duplexes are shown in Table I. We examined the protein expression of TGFßRII by Western blot analysis. As shown in Fig. 3, siT2 and siT3 efficiently inhibited the expression of TGF $\beta$ RII (both $\mathrm{P}<0.05$ ) compared with the scrambled siRNA (mock), and siT2 resulted in a greater inhibition than siT3, whereas there was little difference between the control and mock cells. Overall, the siT2 was identified as the most efficient siRNA to knock down TGF $\beta$ RII expression and the subsequent experiments focused on the siT2.

Inhibition of A549 cell proliferation by TGF $\beta$ RII siRNA. To investigate whether TGF $\beta$ RII down-regulation affected the proliferation of A549 cells, cells were incubated with $2 \mathrm{ng} /$ $\mathrm{ml}$ TGF- $\beta 1$ for $0-72 \mathrm{~h}$ following transfection with TGF $\beta$ RII siRNA and growth rates were determined by the MTT assay. As shown in Fig. 4, SiRNA-TGF $\beta$ RII A549 cell growth was markedly inhibited at $24 \mathrm{~h}(\mathrm{P}<0.05), 48 \mathrm{~h}(\mathrm{P}<0.01)$ and $72 \mathrm{~h}$ $(\mathrm{P}<0.01)$, when compared to the control and mock cells. However, no difference was observed between control and mock cells. Thus, the results indicate that the knockdown of TGF $\beta$ RII may have a negative effect on the proliferation of the LAC cell line, A549.

Inhibition of colony formation by TGF $\beta R I I$ siRNA transfection. To further examine the effects of TGF $\beta$ RII knockdown on the growth properties of A549 cells, positive colony forma- 
A
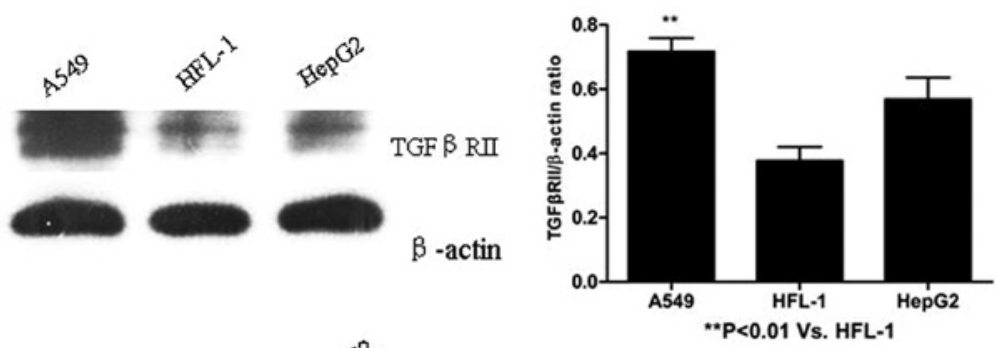

B

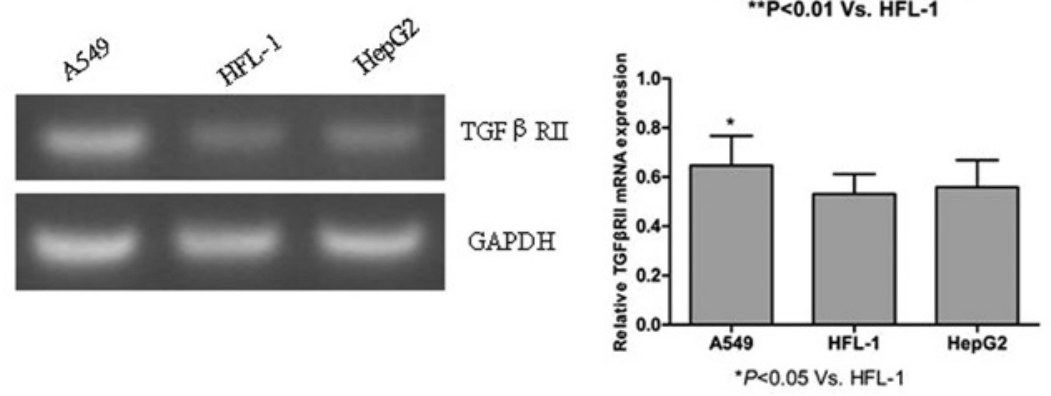

Figure 1. Expression of TGF $\beta$ RII protein and mRNA in various cell lines. (A) TGF $\beta$ RII protein levels. The cellular proteins were extracted with lysis buffer and TGFßRII protein levels were detected by Western blot analysis. The $\beta$-actin protein levels were examined as the control by Western blot analysis. (B) TGF $\beta R$ II mRNA levels. The total RNAs were isolated from the cell lines, A549, HFL-1 and HepG2. The TGFBRIImRNA was analyzed by semiquantitative RT-PCR as described in Materials and methods. The detection of GAPDH levels was included as the control for RT-PCR analysis. "P $<0.05$, "** P<0.01 vs. HFL-1.

A

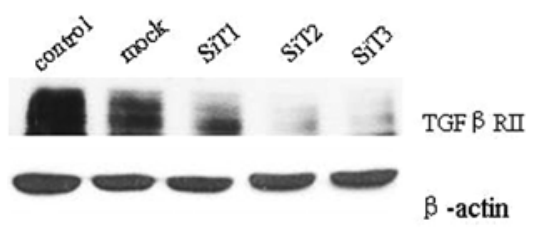

B

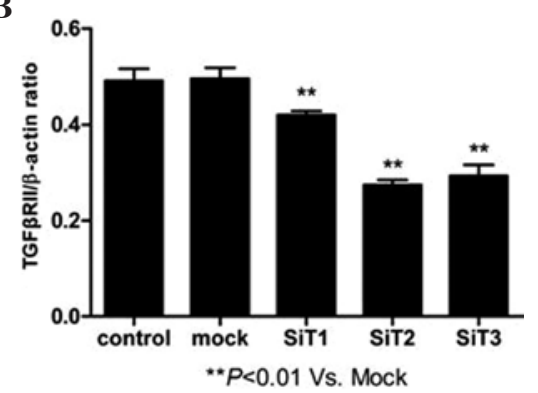

Figure 2. Three siRNAs suppressed the TGFßRII protein expression in the NSCLC cell line, A549. A549 cells were seeded into 6-well plates and transfected with three TGFßRII-specific siRNAs (siT1, siT2 and siT3) and scrambled non-targeting siRNA (mock). The untreated cells were used as the control. The protein expression of each siRNA was measured by Western blot analysis $48 \mathrm{~h}$ after transfection as described in Materials and methods. The siT2 was identified as the most efficient siRNA to knockdown TGFßRII expression. ${ }^{* *} \mathrm{P}<0.01$ vs. mock.

A

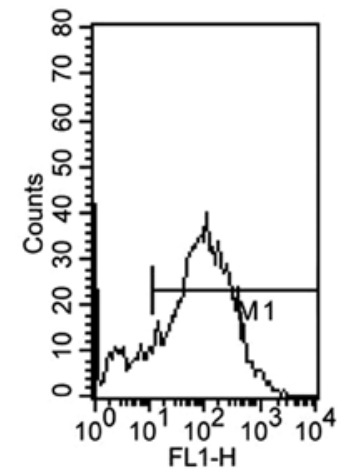

\begin{tabular}{rrrr} 
Marker & \% Gated & Mean & Geo Mean \\
\hline All & 100.00 & 121.53 & 58.49 \\
M1 & 86.46 & 139.84 & 89.93
\end{tabular}
B

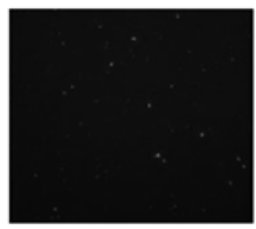

$24 h$

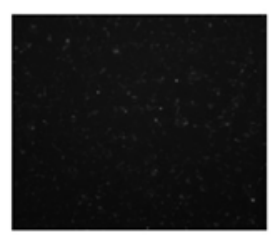

$12 h$

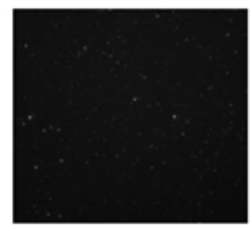

$48 h$

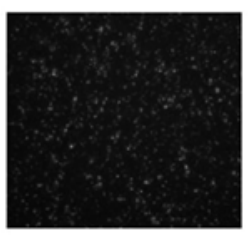

Figure 3. Efficient transfection of TGFßRII siRNA into A549 cells. (A) Detection of transfection efficiency by flow cytometry. A549 cells were transfected with $100 \mathrm{nM}$ fluorescent siRNA for $6 \mathrm{~h}$ then examined by flow cytometry. Transfection efficiency was maintained at over 85\%. (B) Detection of transfection efficiency by fluorescence microscopy. Efficiently transfected A549 cells were clearly identified at 6, 12,24, and 48 h post-transfection by fluorescence microscopy. 


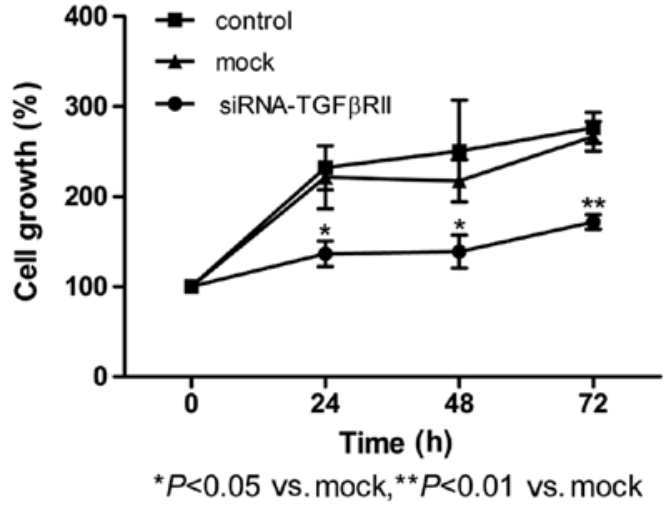

Figure 4 . Blockade of the TGF- $\beta$ signaling pathway with TGF $\beta$ RII siRNA inhibited A549 cell proliferation. A549 cells were seeded into 96-well plates and transfected with TGF $\beta$ RII and scrambled siRNAs (mock) at $100 \mathrm{nM}$ The untreated cells were used as the control. Three groups were incubated with $2 \mathrm{ng} / \mathrm{ml}$ TGF- $\beta 1$ for $0-72 \mathrm{~h}$ and measured at $0,24,48$, and $72 \mathrm{~h}$ by MTT assay. SiRNA-TGFßRIIA549 cell growth was significantly attenuated at $24 \mathrm{~h}(\mathrm{P}<0.05), 48 \mathrm{~h}(\mathrm{P}<0.01)$ and $72 \mathrm{~h}(\mathrm{P}<0.01)$ compared to the mock cells. ${ }^{*} \mathrm{P}<0.05,{ }^{* *} \mathrm{P}<0.01$ vs. mock.

tion ( $>50$ cells/colony) was counted after the control, mock and TGF $\beta$ RII siRNA cells were seeded at a density of 300 cells/ $\mathrm{ml}$ in a 6-well plate and incubated for 14 days. As shown in Fig. 5, SiRNA-TGFßRII cells exhibited a significantly lower colony formation rate than the control and mock cells $(\mathrm{P}<0.01)$. Therefore, TGF $\beta$ RII down-regulation resulted in a reduction in the ability of A549 cells to form colonies.

Targeting TGF $\beta R I I$ siRNA weakens the migratory/invasive ability of A549 cells. TGF- $\beta$ signaling is associated with the biological behavior of tumor cells $(7,14)$, and two critical steps of metastasis are migration and invasion (18). To investigate the effects of the TGF- $\beta$ signaling blockade using TGF $\beta$ RII siRNA on the metastasis of LAC cells, we examined the motility and invasiveness of targeted TGF 3 RII A549 using the wound healing migration and transwell Matrigel invasion assays. In the wound healing assay, TGFßRII siRNA-treated cells exhibited significantly decreased migration and were unable to close the wound when compared with the scrambled siRNA (mock) cells $(\mathrm{P}<0.01)$. The control and mock cells almost achieved complete wound closure $(\mathrm{P}>0.05)$. The results are represented as the migration index (Fig. 6). Furthermore, compared to the mock cells, transwell assays indicated that the number of invasive cells among those treated with TGF $\beta$ RII siRNA was significantly reduced. It was also indicated that the invasive capacity was suppressed, but there was no difference between the control and mock cells (Fig. 7). These results indicate that the targeting of TGFBRII siRNA weakens the migratory and invasive abilities of LAC A549 cells in vivo.

Promotion of apoptosis in TGFBRII knockdown NSCLC A549 cells. To further evaluate whether the TGF $\beta$ RII knockdown induced apoptosis in A549 cells, the cells, which were treated and then incubated with TGF $\beta 1(2 \mathrm{ng} / \mathrm{ml})$ for $24 \mathrm{~h}$, were analyzed by flow cytometry. As shown in Fig. 8, the apoptotic rate in TGFßRII siRNA cells was higher than that in the mock and control cells. The results indicated that the
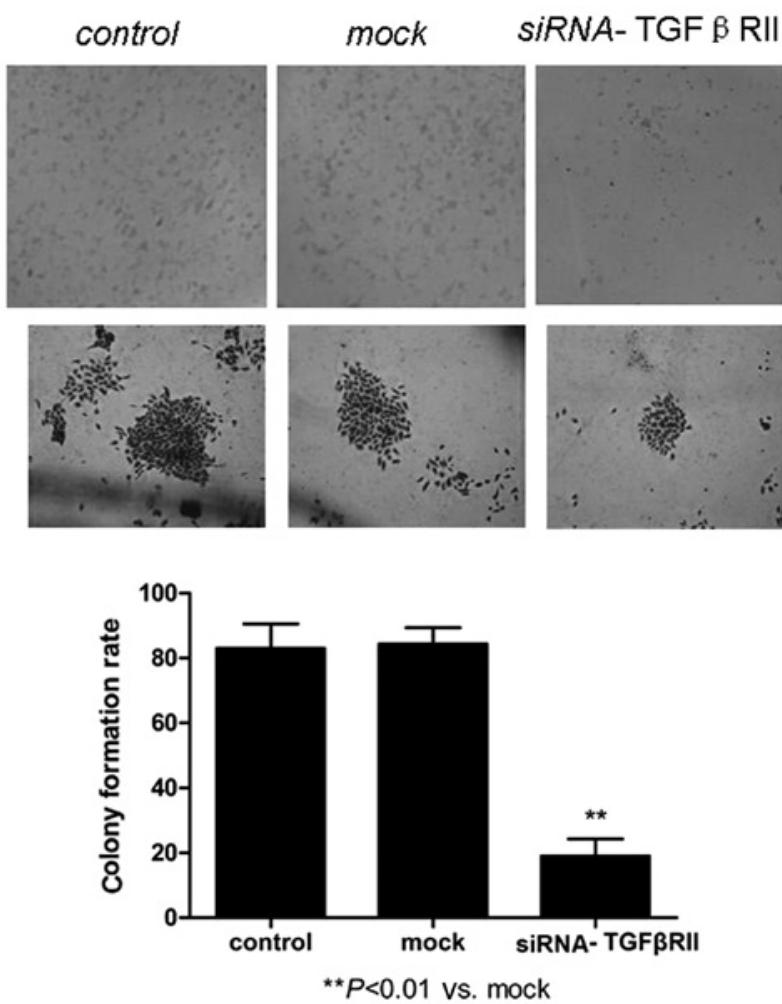

Figure 5. TGF $\beta$ RII knockdown inhibits the colony formation of A549 cells Cells transfected with TGFßRIIsiRNA after $48 \mathrm{~h}$ were seeded in 6-well plates at densities of 300 cells/well and incubated for 14 days. The cells were stained by $0.1 \%$ crystal violet and the positive colony formations ( $>50$ cells/ colony) were counted. Representative microscopy images are shown in addition to a bar graph representing the mean colony formation rate. The results demonstrated that knockdown of TGF $\beta$ RII significantly attenuated the colony formation rate of A549 cells. ${ }^{* *} \mathrm{P}<0.01$ vs. mock.

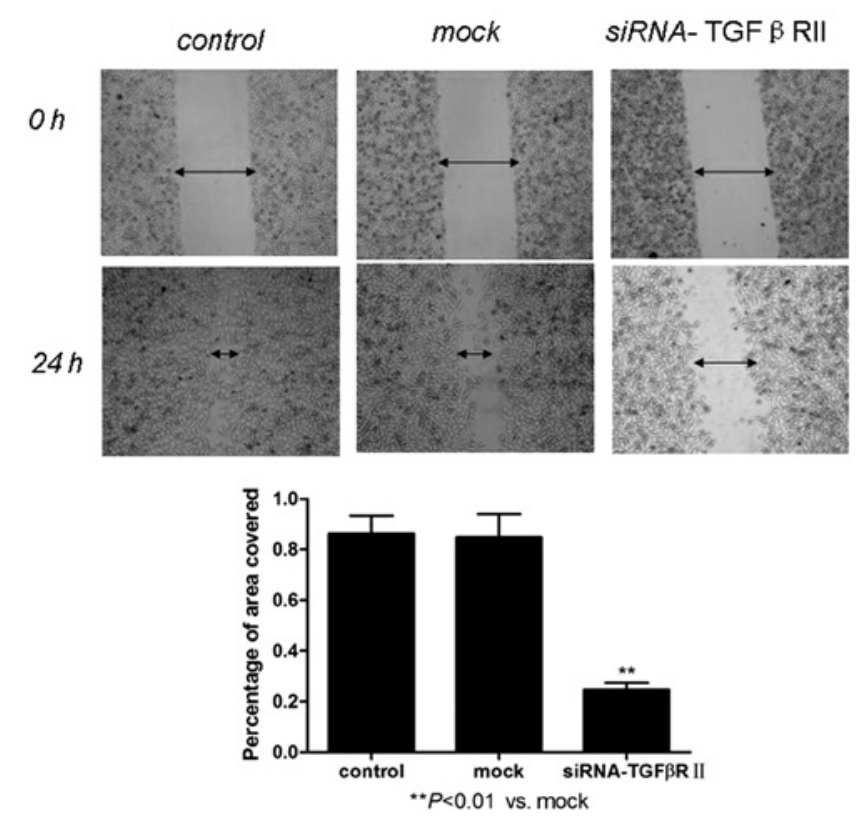

Figure 6. TGF $\beta$ RII siRNA blocked A549 cell migration. A549 cells were transfected in 6-well plates for $48 \mathrm{~h}$ and scratched with a $200 \mu$ l pipette tips at approximately $90 \%$ confluency. Cells, which were then incubated with the complete growth medium without FBS, migrated into the wounded area and were photographed. Data and representative images are shown (magnification, $\mathrm{x} 40$ ) in addition to a bar graph showing the mean percentage of the wound area covered by migrating A549 cells. A549 cells treated with TGFßRII siRNA showed a marked decreased in cell motility. ${ }^{*} \mathrm{P}<0.01$ vs. mock. 

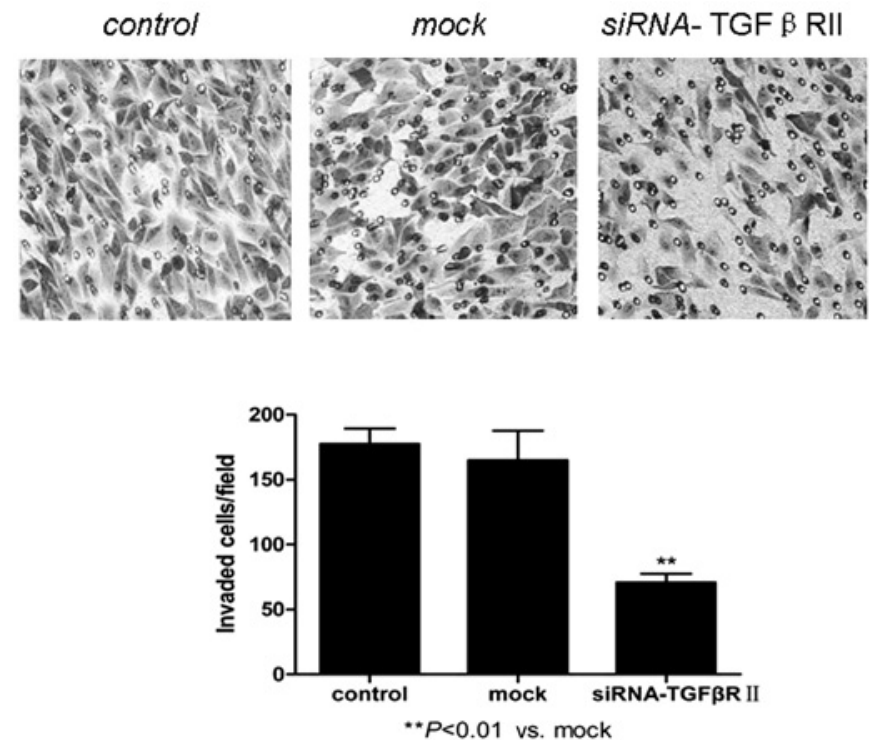

Figure 7. TGF $\beta$ RII knockdown attenuated invasion of A549 cells. After transfection with siRNA for $48 \mathrm{~h}$, Cells were harvested and $100 \mu \mathrm{l}$ homogeneous single cell suspensions $\left(2 \times 10^{5}\right.$ cells/well $)$ were added to the Matrigel-coated Transwell upper chambers. Cells penetrating the membrane were stained with $0.1 \%$ crystal violet and photographed. Representative microscopy images (magnification, x200) are shown. Bar chart represents the mean number of the cells per field. Knockdown of TGF $\beta$ RII by siRNA in A549 cells inhibited cell invasion. ${ }^{* *} \mathrm{P}<0.01$ vs. mock.

inhibition of TGF $\beta$ RII expression promoted apoptosis in the TGF $\beta$ RII-knockdown LAC A549 cells.

Molecular mechanisms of the anti-tumor effects by TGFBRII knockdown. The protein from cells in the three groups was extracted to examine the effects of the TGFßRII knockdown on the expression and phosphorylation status of specific cytokines and signaling molecules. We observed that the protein expression levels of PI3K, phosphorylated Akt, phosphorylated Erk1/2, phosphorylated P38, phosphorylated Smad2 and Smad4 were decreased in the TGF $\beta$ RII siRNA cells, while those in the control and mock cells exhibited no difference (Fig. 9A and B). These results indicate that the TGFßRII knockdown significantly inhibits intracellular growth factor signaling molecules in LAC cells. In addition, TGF $\beta$ RII knockdown decreased the protein expression of MMP-9 and VEGF, which have been demonstrated to directly promote carcinogenesis and cancer progression (19-21). However, MMP-2 expression was not changed (Fig. 9C). Together, these data demonstrate that TGF $\beta$ RII knockdown in LAC cells plays a role in anti-tumor activity via the inhibition of downstream proliferation pathways.

\section{Discussion}

Despite advances in medical and surgical treatments, lung cancer is the leading cause of cancer deaths (approximately 1.3 million deaths/year) (2). Prognosis in main histological types of lung cancer is poor, due to intrinsic properties of LAC, whose cells exhibit a marked ability to rapidly progress (22-23). Tumor progression includes tumor cell proliferation, invasion (loss of cell-to-cell adhesion, increased cell motility
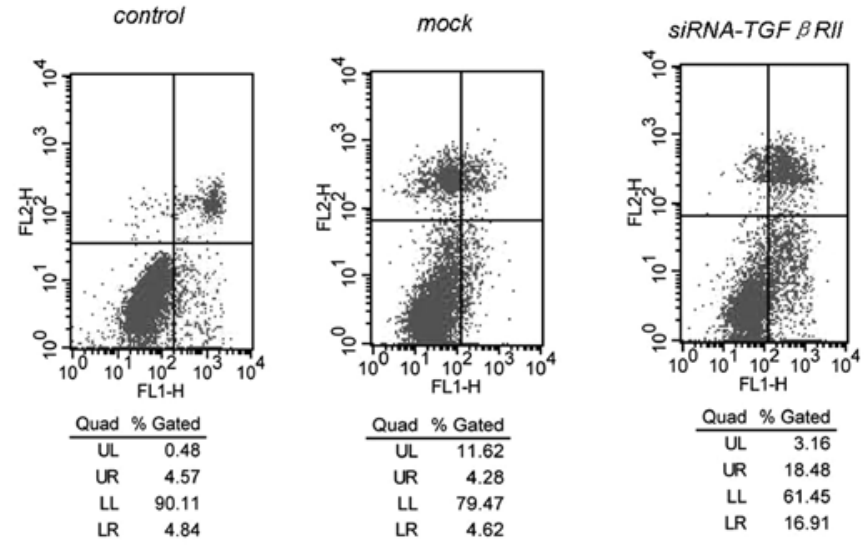

Figure 8 . Blockade of the TGF- $\beta$ signaling pathway with TGF $\beta$ RII siRNA induced apoptosis of A549 cells. A549 cells were transfected in 6-well plates and exposed to TGF $\beta 1(2 \mathrm{ng} / \mathrm{ml})$ for $48 \mathrm{~h}$. The cells labeled with Annexin V-FITC and propidium iodide were subjected to flow cytometric analysis. TGF $\beta$ RII siRNA increased the apoptotic rate in A549 cells, whereas scramble siRNA did not. Two parameter histogram Dot Plot displayed FL1-FITC on the $\mathrm{x}$ axis and FL2-PI on the $\mathrm{y}$ axis.

and basement membrane degradation) and vascular intravasation and extravasation, establishment of a metastatic niche, and angiogenesis (24-25). Therefore, effective inhibition of the proliferative and metastatic biological behavior of LAC cells is crucial for the improvement ofpatient outcomes.

TGF $\beta$ RII is a transmembrane receptor and mediates the TGF- $\beta$ signaling pathway during TGF- $\beta$ binding. In the present study, we revealed that TGF $\beta$ RII overexpression can be detected in the LAC cell line, A549, whereas its expression in human normal HFL-1 and human hepatic carcinoma HepG2 cell lines is relatively low. In normal tissue/cells, the TGF- $\beta$ signaling pathway sustains homeostasis and prevents tumorigenesis by inhibiting cellular proliferation, differentiation, and survival $(6,26-27)$. Destruction of TGF- $\beta$ signaling (especially TGF $\beta$ RII) clearly induces tumorigenicity (28). However, tumors frequently lose their negative growth response to TGF- $\beta$ and, in contrast, TGF- $\beta$ signaling may promote tumor cell invasion and metastasis due to its ability to stimulate angiogenesis, alter the stromal environment, and significantly, cause local and systemic immunosuppression $(8,28-31)$. Since it is still unclear as to whether TGF- $\beta$ signaling plays a biological role in LAC progression, we focused on TGF $\beta$ RII knockdown in LAC cells A549 to investigate the anti-tumor function of TGF $\beta$ RII in vitro using RNA interference.

In this study, we designed and chemically synthesized three siRNAs to specifically target TGFßRII (named as siT1, siT2 and siT3) in human LAC cells A549. Transfection efficiency was above $85 \%$ and the efficacy of the siRNAs persisted for at least $48 \mathrm{~h}$ without significant degradation. In addition, Western blot analysis revealed that, of the three siRNAs tested, siT2 was the most efficacious in the two protein levels. The establishment of siRNA-mediated gene silencing was reliable due to the use of siRNAs designed against different regions of the TGF $\beta$ RII gene (32).

When tissue and tumor cells overexpress TGF- $\beta$ and lose the growth-inhibitory response to TGF- $\beta$, this is associated with malignant conversion and progression (26-28,30-31). 

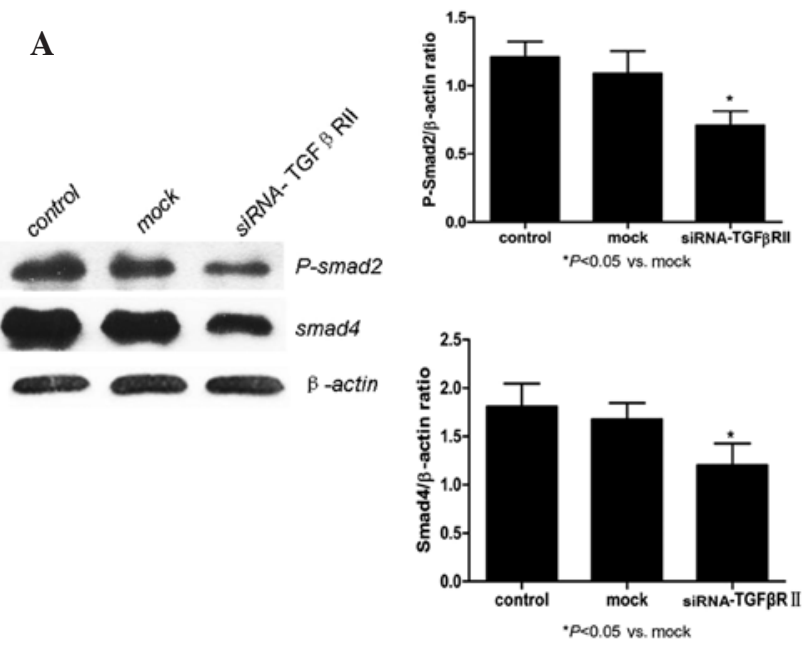

Bb
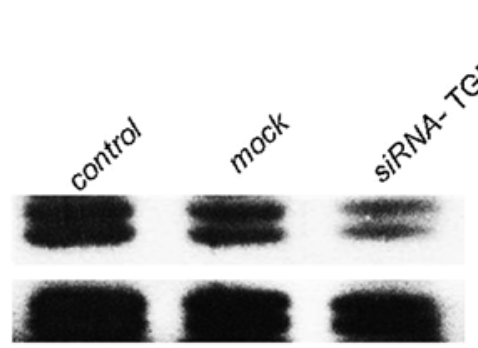

P-Erk1/2

Erk1/2

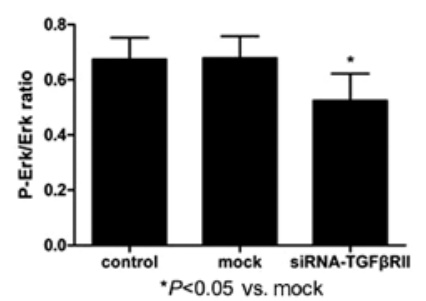

Ca
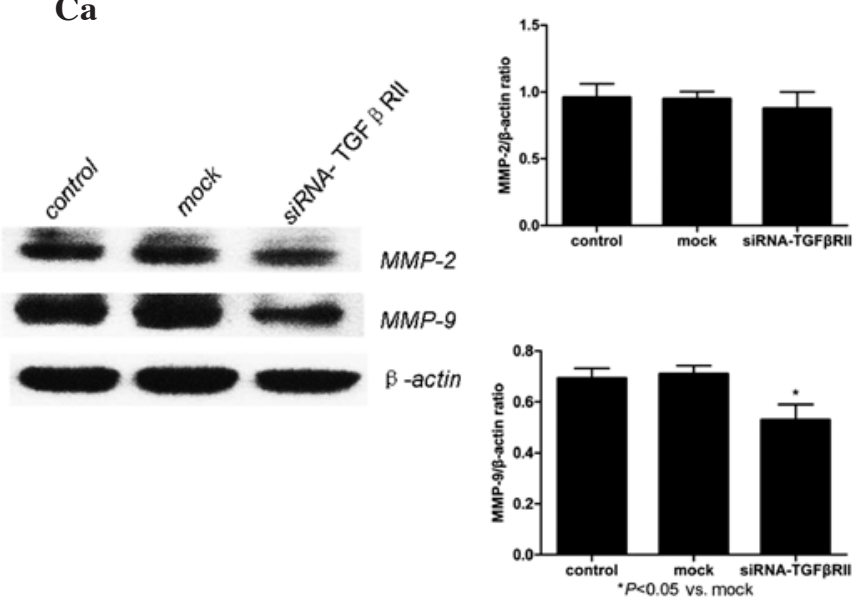
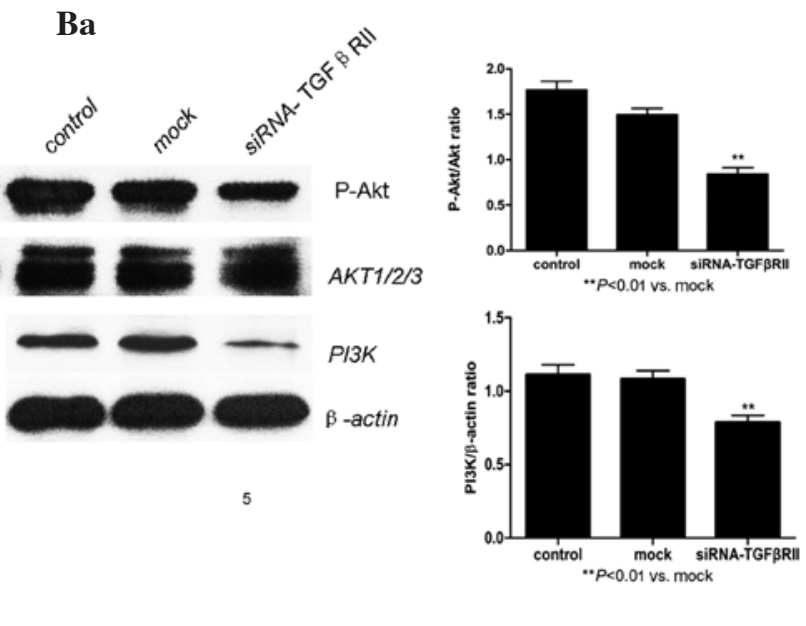

Bc
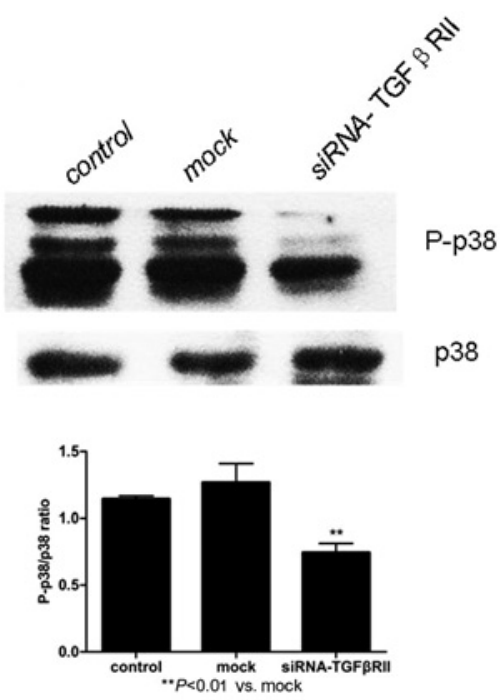

$\mathrm{Cb}$
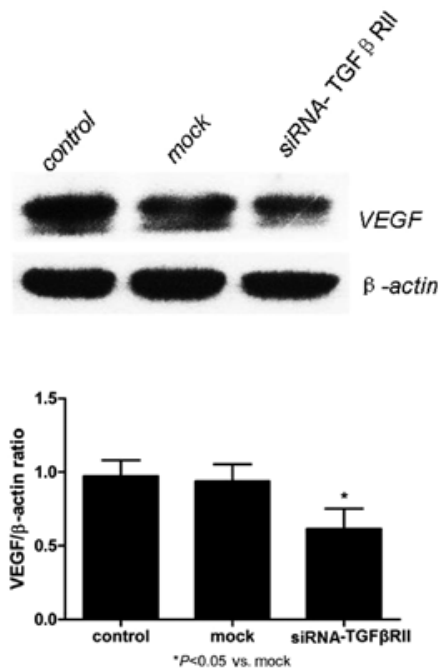

Figure 9. Western blot analysis of the anti-tumor effects by blockade of TGF- $\beta$ signaling pathway with TGF $\beta$ RII siRNA. The A549 cells treated with TGF $\beta$ RII siRNA or scrambled siRNA for $48 \mathrm{~h}$ and control cells were incubated with TGF- $\beta \mathrm{I}$ ( $2 \mathrm{ng} / \mathrm{ml})$ for $2 \mathrm{~h}$, and then total cell protein was extracted The levels of PI3K, phosphorylated Akt, phosphorylated Erk1/2, phosphorylated P38, phosphorylated Smad2 and phosphorylated Smad4 were examined by Western blot analysis. (A) Effects of TGF $\beta$ RII knockdown on Smad protein-dependent pathway. Activation of Smad2 and Smad4 in A549 cells treated with TGF $\beta$ RII siRNA were relatively diminished after TGF- $\beta$ stimulation. (Ba-c) Effects of TGF $\beta$ RI knockdown on the Smad protein independent pathway. Similar to the Smad protein dependent pathway, the activation of PI3K/Akt, Erk1/2 MAPK and P38 MAPK in cells transfected with TGF 3 RII siRNA was inhibited. (Ca-b) Effects of TGFßRII knockdown on MMPs and VEGF. The protein expression levels of MMP-9 and VEGF in TGF 3 RII-knockdown A549 cells were relatively diminished, whereas the MMP-2 was unchanged. ${ }^{*} \mathrm{P}<0.05,{ }^{* *} \mathrm{P}<0.01$ vs. mock. 
Numerous tumor types, including NSCLC, express a high level of TGF- $\beta$ (9-10), but the relationship between LAC cells growth and TGF- $\beta$ signaling has yet to be established. In the present study, we observed that the down-regulation of TGF $\beta$ RII expression inhibited TGF- $\beta$ signaling and led to suppression of the proliferation of A549 cells: these effects were time-dependent. Additionally, the tumor colony-forming assay revealed that the clonogenic potential of TGF 3 RII knockdown A549 cells was greatly reduced. Therefore, impairment of TGF- $\beta$ signaling through the knockdown of the TGFßRII gene attenuated the ability of A549 cells to proliferate and form colonies. Furthermore, we observed that apoptosis was moderately induced by siRNA targeting TGF $\beta$ RII for $48 \mathrm{~h}$. The signaling pathways mediating LAC cell growth, including the Smad protein-dependent (e.g. Smad2, Smad4) and -independent pathways (e.g. Erk MAPK, PI3K/Akt, p38 MAPK), are complex (6-8). We observed the consequences of the down-regulation of TGF $\beta$ RII expression on TGF- $\beta$ signaling pathways, which were that the protein expression levels of phosphorylated Smad2, Smad4, PI3K, phosphorylated Akt, phosphorylated Erk $1 / 2$ and phosphorylated P38 decreased, whereas there were no differences between the control and mock cells. TGF- $\beta$ signaling blockade through siRNA targeting TGF $\beta$ RII may therefore inhibit the uncontrolled growth of LAC cells and lead to apoptosis via downstream signaling molecules.

In addition to the involvement in the growth of A549 cells, we observed that the capabilities for invasion and metastasis in vitro were attenuated following siRNA-mediated TGF $\beta$ RII knockdown, which is consistent with previous studies showing that TGF- $\beta$ signaling is required for carcinoma cell invasiveness and metastasis (e.g., in pancreatic cancer, breast carcinoma, glioblastoma and colon carcinoma cells) (11-14). The matrix metalloproteinases (MMPs) are a family of enzymes that degrade proteins in tissue extracellular matrices. These proteinases are clearly involved in cancer progression, including tumor cell degradation of basement membranes and stroma, blood vessel penetration, and angiogenesis (24). Although it has been established that the overexpression of MMP-2 and MMP-9 in lung cancer cells plays a role in invasion and metastasis (33-34), the manner in which TGF- $\beta$ signaling regulates the expression of MMP-2 and/or MMP-9 in LAC remains unclear. The present study demonstrates for the first time that TGF- $\beta$ signaling blockade suppresses the expression of MMP-9 but that MMP-2 expression was unaltered by the knockdown of TGFßRII using siRNA. In addition, LAC progression and metastasis depend upon angiogenesis, in which the vascular endothelial growth factor (VEGF) plays a core role (21). In the present study, we also observed the suppression of VEGF expression in the knockdown of TGFßRII A549 cells. Thus, we hypothesize that the TGF- $\beta$ signaling pathway regulates MMP-9 and VEGF expression in LAC A549 cells to promote tumor progression. However, the mechanisms of this process require further investigation.

In conclusion, these results reveal that TGF- $\beta$ signaling blockade using TGF $\beta$ RII-targeting SiRNA can inhibit LAC cell proliferation, invasion and metastasis and induce cell apoptosisis. Therefore, we have identified that TGF- $\beta$ signaling plays an important role in LAC progression and MMPs and VEGF may be closely associated with TGF- $\beta$ signaling pathway. Efficient silencing of TGFßRII using
RNA interference may be a potential modality for the gene therapy of LAC. Although the results were relatively favorable in vitro, further research in vivo is warranted to confirm the effectiveness and safety of anti-cancer therapy with TGFßRII-targeting SiRNA.

\section{Acknowledgments}

The study was partially supported by the scientific and technological project of Hubei Province, China (2008CBD142).

\section{References}

1. Parkin DM, Bray F, Ferlay J and Pisani P: Global cancer statistics, 2002. CA Cancer J Clin 55: 74-108, 2005.

2. Jemal A, Siegel R, Xu J and Ward E: Cancer statistics, 2010. CA Cancer J Clin 60: 277-300, 2010.

3. Hanagiri T, Baba T, So T, et al: Time trends of surgical outcome in patients with non-small cell lung cancer. J Thorac Oncol 5: 825-829, 2010.

4. Hocking WG, Hu P, Oken MM, et al: Lung cancer screening in the randomized Prostate, Lung, Colorectal, and Ovarian (PLCO) Cancer Screening Trial. J Natl Cancer Inst 102: 722-731, 2010.

5. Lonardo F, Li X, Kaplun A, et al: The natural tumor suppressor protein maspin and potential application in non small cell lung cancer. Curr Pharm Des 16: 1877-1881, 2010.

6. Derynck $R$ and Zhang YE: Smad-dependent and Smadindependent pathways in TGF-beta family signalling. Nature 425: 577-584, 2003.

7. Massague J: TGFbeta in Cancer. Cell 134: 215-230, 2008.

8. Toonkel RL, Borczuk AC and Powell CA: Tgf-beta signaling pathway in lung adenocarcinoma invasion. J Thorac Oncol 5: 153-157, 2010.

9. Saji H, Nakamura H, Awut I, et al: Significance of expression of TGF-beta in pulmonary metastasis in non-small cell lung cancer tissues. Ann Thorac Cardiovasc Surg 9: 295-300, 2003.

10. Hasegawa Y, Takanashi S, Kanehira Y, Tsushima T, Imai T and Okumura K: Transforming growth factor-betal level correlates with angiogenesis, tumor progression, and prognosis in patients with nonsmall cell lung carcinoma. Cancer 91: 964-971, 2001.

11. Ganapathy V, Ge R, Grazioli A, et al: Targeting the Transforming Growth Factor-beta pathway inhibits human basal-like breast cancer metastasis. Mol Cancer 9: 122, 2010.

12. Rowland-Goldsmith MA, Maruyama H, Kusama T, Ralli S and Korc M: Soluble type II transforming growth factor-beta (TGF-beta) receptor inhibits TGF-beta signaling in COLO-357 pancreatic cancer cells in vitro and attenuates tumor formation. Clin Cancer Res 7: 2931-2940, 2001.

13. Wesolowska A, Kwiatkowska A, Slomnicki L, et al: Microgliaderived TGF-beta as an important regulator of glioblastoma invasion - an inhibition of TGF-beta-dependent effects by shRNA against human TGF-beta type II receptor. Oncogene 27: 918-930, 2008.

14. Oft M, Heider $\mathrm{KH}$ and Beug $\mathrm{H}$ : TGFbeta signaling is necessary for carcinoma cell invasiveness and metastasis. Curr Biol 8: 1243-1252, 1998.

15. Kim DH and Rossi JJ: Strategies for silencing human disease using RNA interference. Nat Rev Genet 8: 173-184, 2007.

16. Lu PY, Xie F and Woodle MC: In vivo application of RNA interference: from functional genomics to therapeutics. Adv Genet 54: 117-142, 2005.

17. Kruger NJ: The Bradford method for protein quantitation. Methods Mol Biol 32: 9-15, 1994.

18. Friedl $\mathrm{P}$ and Wolf $\mathrm{K}$ : Tumour-cell invasion and migration: diversity and escape mechanisms. Nat Rev Cancer 3: 362-374, 2003.

19. Hawinkels LJ, Zuidwijk K, Verspaget HW, et al: VEGF release by MMP-9 mediated heparan sulphate cleavage induces colorectal cancer angiogenesis. Eur J Cancer 44: 1904-1913, 2008.

20. Himelstein BP, Canete-Soler R, Bernhard EJ, Dilks DW and Muschel RJ: Metalloproteinases in tumor progression: the contribution of MMP-9. Invasion Metastasis 14: 246-258, 1994.

21. Ferrara N, Gerber HP and LeCouter J: The biology of VEGF and its receptors. Nat Med 9: 669-676, 2003. 
22. Devesa SS, Bray F, Vizcaino AP and Parkin DM: International lung cancer trends by histologic type: male:female differences diminishing and adenocarcinoma rates rising. Int J Cancer 117: 294-299, 2005

23. Janssen-Heijnen ML and Coebergh JW: The changing epidemiology of lung cancer in Europe. Lung Cancer 41: 245-258, 2003.

24. Deryugina EI and Quigley JP: Matrix metalloproteinases and tumor metastasis. Cancer Metastasis Rev 25: 9-34, 2006.

25. Duffy MJ, McGowan PM and Gallagher WM: Cancer invasion and metastasis: changing views. J Pathol 214: 283-293, 2008.

26. Guasch G, Schober M, Pasolli HA, Conn EB, Polak L and Fuchs E: Loss of TGFbeta signaling destabilizes homeostasis and promotes squamous cell carcinomas in stratified epithelia. Cancer Cell 12: 313-327, 2007.

27. Wrzesinski SH, Wan YY and Flavell RA: Transforming growth factor-beta and the immune response: implications for anticancer therapy. Clin Cancer Res 13: 5262-5270, 2007.

28. McCartney-Francis NL, Frazier-Jessen $M$ and Wahl SM TGF-beta: a balancing act. Int Rev Immunol 16: 553-580, 1998.
29. Elliott RL and Blobe GC: Role of transforming growth factor Beta in human cancer. J Clin Oncol 23: 2078-2093, 2005.

30. Roberts $\mathrm{AB}$ and Wakefield LM: The two faces of transforming growth factor beta in carcinogenesis. Proc Natl Acad Sci USA 100: 8621-8623, 2003.

31. Derynck R, Akhurst RJ and Balmain A: TGF-beta signaling in tumor suppression and cancer progression. Nat Genet 29: 117-129, 2001.

32. Semizarov D, Frost L, Sarthy A, Kroeger P, Halbert DN and Fesik SW: Specificity of short interfering RNA determined through gene expression signatures. Proc Natl Acad Sci USA 100: 6347-6352, 2003.

33. Roy R, Yang J and Moses MA: Matrix metalloproteinases as novel biomarkers and potential therapeutic targets in human cancer. J Clin Oncol 27: 5287-5297, 2009

34. Shou Y, Hirano T, Gong Y, et al: Influence of angiogenetic factors and matrix metalloproteinases upon tumour progression in non-small-cell lung cancer. Br J Cancer 85: 1706-1712, 2001. 
